\title{
A COMPARISON OF PHYSICAL EFFICIENCY BETWEEN INDIAN PHYSICAL EDUCATION AND MEDICAL STUDENTS
}

\author{
A. K. DE, D.C.H., M.D., ${ }^{*}$ P. K. DEBNATH, Ph.D., ${ }^{*}$ \\ D. C. ROY, M.D. ${ }^{* *}$ and J. NAGCHAUDHURI, M.B., B.S., Ph.D.* \\ *Unit of Sports Medicine and Pulmonary Physiology, Department of Physiology, \\ * *Department of Pharmacology, \\ ** *Department of Tuberculosis and Chest Diseases, \\ Institute of Medical Sciences, \\ Banaras Hindu University, \\ VARANASI-221 005, \\ INDIA
}

\begin{abstract}
The recovery pulse and respiration were analysed to determine the level of physical fitness among the physical education and medical students of Banaras Hindu University. The analysis of the data suggested that physical fitness as measured by recovery rate was better in physical education students than in medical students. Following questionnaire method, it has been noted that the daily activity of physical education students was more than the medical students and probably the reason for higher efficiency in them.
\end{abstract}

\section{INTRODUCTION}

Several methods have been employed for assessing the physical fitness of the individual. These include measurements of response to various types of physical activity, Bengetsson (1956), Boas (1931), Bowen (1904), Gallagher (1944), Kraus and Prudden (1954) and Schneider (1920), endurance tests, Cogswell, Henderson et al (1946), ability to perform the prescribed physical feats, Le Blance (1957), and the evaluation of rate of recovery after exercise, Boas (1931), Gallagher (1944), Joseph (1974) and Sharman, Down et al (1976). It is well known that in normal individuals, working within their aerobic capacities, a linear relationship exists between the amount of work performed and oxygen consumption, cardiac output and pulse rate. Further, the physical fitness of the individual has an obvious relationship with the degree of increase of the cardiac output and pulse rate with the exercise. Therefore, to evaluate the physical fitness of an individual, the response of the cardio-respiratory system to exercise with known amounts of generalised work performed on a cycle ergometer is accepted as one of the standard tests, Holmegren and Mattsson (1954), Schneider (1931), Sjøstrand (1947), Tuttle (1950) and Wahlund (1948). This study was undertaken to assess the level of fitness among

Address for Correspondence:-

Dr. A. K. De,

Department of Physiology,

Institute of Medical Sciences,

Varanasi-221 005,

INDIA physical education and medical students, and to compare the two groups.

The study was conducted on male volunteers of two groups, " $M$ " medical students between the ages of 19-21 years (average 19 y $9 \mathrm{~m}$ ) and "PE" physical education students aged between 22-27 years (average $24 \mathrm{y}$ ) of Banaras Hindu University. Compared with students of physical education, medical students were comparatively inactive, as regards sports and general physical activity. Both groups of subjects were given a workload by means of the cycle ergometer (INCO). The steady rate of pedalling $(100 \pm 5 / \mathrm{min})$ was maintained by a metronome and continued for 6 minutes. A total load of $49.1 \pm 2.5 \mathrm{Kj}$ i.e. a work rate of approx. $140 \mathrm{w}$, was constant for all the subjects studied. The ventilation volume was measured by a spirometer (Max Plank Institute, W.G.).

Before starting the experiment, sufficient time was allowed to record the pulse and respiration rates with the subject seated. These were also noted immediately after exercise for $15 \mathrm{sec}$ and up to $1 \mathrm{~min}$ of recovery. Then the pulse rates were taken for $30 \mathrm{sec}$ each minute until the pre-exercise rates were attained.

\section{RESULTS}

The data obtained to assess the level of physical fitness among the two groups of subjects studied, group $M$ and group PE are shown in Tables I and II.

It was observed that the resting pulse rates of group $M$ are higher than those of group PE, $p<0.025$. The 
TABLE I

Physical characteristics and respiratory data (means \pm S.D. and range)

\begin{tabular}{|c|c|c|c|c|c|}
\hline & $\begin{array}{l}\text { Age } \\
\text { (years) }\end{array}$ & Height $(\mathrm{cm})$ & Weight (kg) & $\begin{array}{l}\text { Pre-test } \\
\text { respiration } \\
\text { rate/min }\end{array}$ & $\begin{array}{l}\text { Time of } \\
\text { recovery of } \\
\text { respiration }(\mathrm{min})\end{array}$ \\
\hline $\begin{array}{l}\text { medical } \\
\text { students } \\
\text { (group M) } \\
n=11\end{array}$ & $\begin{array}{l}19.9 \pm 0.7 \\
(19-21)\end{array}$ & $\begin{array}{l}171.1 \pm 6.0 \\
(161-178)\end{array}$ & $\begin{array}{l}58.4 \pm 2.58 \\
(52-71)\end{array}$ & $\begin{array}{l}15.9 \pm 1.55 \\
(13-18)\end{array}$ & $\begin{array}{l}11.9 \pm 2.97 \\
(3-32)\end{array}$ \\
\hline $\begin{array}{l}\text { physical } \\
\text { education } \\
\text { students } \\
\text { (group PE) } \\
n=11\end{array}$ & $\begin{array}{l}24.0 \pm 1.7 \\
(22-27)\end{array}$ & $\begin{array}{l}174.3 \pm 2.4 \\
(161-183.5)\end{array}$ & $\begin{array}{l}62.0 \pm 2.11 \\
(58-70) \\
* *\end{array}$ & $\begin{array}{l}19.0 \pm 1.72 \\
(14-22) \\
* * *\end{array}$ & $\begin{array}{l}6.8 \pm 1.98 \\
(2-16) \\
* * *\end{array}$ \\
\hline
\end{tabular}

TABLE II

Pulse data of the two groups (mean \pm S.D. and range)

\begin{tabular}{|c|c|c|c|c|c|c|c|c|c|}
\hline & \multirow{2}{*}{$\begin{array}{l}\text { Pre-test } \\
\text { pulse } \\
\text { rate }\end{array}$} & \multicolumn{3}{|c|}{ RECOVERY PULSE RATES } & \multirow[b]{2}{*}{$4-4 \frac{1}{2} \min$} & \multirow[b]{2}{*}{$\begin{array}{l}\text { Total of } \\
31 / 2 \text { min } \\
\text { pulse } \\
\text { beats }\end{array}$} & \multirow[b]{2}{*}{$\begin{array}{l}\ln 3 \\
\min \end{array}$} & \multirow[b]{2}{*}{$\begin{array}{l}\text { Increase } \\
\text { of pulse } \\
\text { during } 3 \\
\text { min of } \\
\text { recovery } \\
\text { over pre- } \\
\text { test }\end{array}$} & \multirow[b]{2}{*}{$\begin{array}{l}\text { Time for } \\
\text { recovery } \\
\text { of pulse I } \mathrm{min}\end{array}$} \\
\hline & & $\begin{array}{l}\text { During } \\
\text { first } 15 \\
\text { sec }\end{array}$ & $1-11 / 2 \mathrm{~min}$ & $2-21 / 2 \min$ & & & & & \\
\hline $\begin{array}{l}\text { medical } \\
\text { students } \\
\text { (group M) } \\
n=11\end{array}$ & $\begin{array}{l}80.0 \pm \\
5.6 \\
(74-90)\end{array}$ & $\begin{array}{l}33.7 \pm \\
3.7 \\
(27-40)\end{array}$ & $\begin{array}{l}55.7 \pm \\
9.8 \\
(45-70)\end{array}$ & $\begin{array}{l}54.9 \pm \\
8.9 \\
(45-71)\end{array}$ & $\begin{array}{l}51.9 \pm \\
7.5 \\
(43-67)\end{array}$ & $\begin{array}{l}162.5 \pm \\
4.8 \\
(136-208)\end{array}$ & $\begin{array}{l}355.1 \pm \\
45.0 \\
(298-418)\end{array}$ & $\begin{array}{l}114.8 \pm \\
38.6 \\
(46-190)\end{array}$ & $\begin{array}{l}27.0 \pm \\
3.57 \\
(10-46)\end{array}$ \\
\hline $\begin{array}{l}\text { physical } \\
\text { education } \\
\text { students } \\
\text { (group PE) } \\
n=11\end{array}$ & $\begin{array}{l}74.7 \pm \\
2.9 \\
(60-88) \\
*\end{array}$ & $\begin{array}{l}22.3 \pm \\
3.3 \\
(19-28) \\
* * *\end{array}$ & $\begin{array}{l}39.8 \pm \\
5.6 \\
(30-48) \\
* * *\end{array}$ & $\begin{array}{l}41.2 \pm \\
5.7 \\
(31-52) \\
* * *\end{array}$ & $\begin{array}{l}40.7 \pm \\
4.6 \\
(33-49) \\
* * *\end{array}$ & $\begin{array}{l}121.7 \pm \\
3.8 \\
(94-149) \\
*_{* *}^{*}\end{array}$ & $\begin{array}{l}250.4 \pm \\
33.5 \\
(198-312) \\
* * *\end{array}$ & $\begin{array}{l}26.9 \pm \\
27.5 \\
(4-84) \\
* * *\end{array}$ & $\begin{array}{l}9.7 \pm \\
2.28 \\
(3-21) \\
* * *\end{array}$ \\
\hline $\begin{aligned} *{ }^{*} P & <0.0 \\
{ }^{*} * P & <0.0 \\
{ }^{*} P & <0.0\end{aligned}$ & & & & & & & & & \\
\hline
\end{tabular}

pulse rate during first $15 \mathrm{sec}$ of the recovery period is assumed to be equivalent to the last minute of the exercise, Consolazio et al (1963). Group M showed a higher pulse rate during the first $15 \mathrm{sec}$ of the recovery period than did group PE and therefore we assume attained a higher pulse rate during the last minute of exercise. Further, the pulse rates noted during the subsequent periods of recovery e.g. $1-1 \frac{1}{2} \mathrm{~min}, 2-2 \frac{1}{2} \mathrm{~min}$, $4-4 \frac{1}{2} \mathrm{~min}$ and the total of those values, as well as the total recovery periods, were higher in group $M$ than in group PE $(p<0.001)$. The increased pulse rate during the $3 \mathrm{~min}$ of recovery was higher in group $M$ than group

$\operatorname{PE}(p<0.001)$. The resting respiration rate and the recovery time were also higher in group $M$ than in group 0 PE $(p<0.001)$ and the total ventilation volume was also higher in group $M$.

\section{DISCUSSION}

Heart rate increases with the severity of exercise. Stabilisation of the heart rate is achieved during steady state exercise and depends upon the severity of work, body weight, age, physical condition, environmental temperature and atmospheric pressure. It is well known that the 
heart rate during submaximal exercise is remarkably uniform for a given individual under standard environmental conditions and similar measurements can be anticipated in another individual of similar physical fitness and efficiency. In this study, the heights and weights are similar in both groups but their daily activity patterns varied. Their histories suggest that the medical students were comparatively inactive compared with the physical education students.

Le Blance (1957) suggested that the primary factors involved in muscular exercise are related to the oxygen supply to the working muscles and to heat dissipation; consequently, these factors are dependent on how the cardio-respiratory system adapts itself during and after exercise. Further, a direct relationship exists between the pulse rate and the efficiency of the cardio-respiratory adaptation. The continuous increase of pulse and respiration rates as well as the delayed attainment of a steady state during exercise at higher work levels, are indications of an inadequate blood supply to the exer- cising muscles Müller (1957). The less the standard of physical fitness and efficiency, the higher the pulse rate and delayed recovery period with higher oxygen consumption (Dill, 1942). The recovery pulse and respiration rates as well as the recovery time have a direct correlation with the degree of exercise and fitness of the individual. In this study, an identical work load during exercise with a smaller rise of pulse rate during the initial recovery phase, as well as a shorter total recovery time, are suggestive of the higher efficiency of physical education compared with medical students Berggren and Christensen (1950) and Müller (1957). Regarding respiration, similar findings again suggest higher efficiency among the physical education students, Matusi et al (1964) and Nitu et al (1964). The higher oxygen uptakes among the students of physical education are due to their programmed training and might be the cause of their higher efficiency compared with the medical students who were comparatively untrained and of sedentary habit, Durnin et al (1960) and Harmenson and Andersen (1965).

\section{REFERENCES}

Bengetsson, E. 1956. Working capacity in normal children evaluated by submaximal exercise on the bicycle ergometer and compared with adults. Acta Med.Scand. 154: 91.

Berggren, G. and Chrisensen, E. H. 1950. Heart rate and body temperature as indices of metabolic rate during work. Arbeitsphysiologie 14: 255.

Boas, E. P. 1931. Heart-rate of boys during and after exhaustive exercise. J.Clin.Invest. 10: 145.

Bowen, W. P. 1904. Changes in heart-rate, blood pressure and duration of systole resulting from bicycling. Am.J.Physiol. 11: 59.

Cogswell, R. C., Henderson, C. R. and Berryman, G. H. 1946. Some observations of the effects of training on pulse rate, blood pressure and endurance in humans using the step test (Harvard), tread mill and electrodynamic brake bicycle ergometer. Am.J.Physiol. 146: 422.

Consolazio, C. F., Johnson, E. and Pecora, L. J. 1963. Physiological measurements of metabolic functions in men. McGraw Hill, New York, 394.

Dill, D. B. 1942. Effects of physical strain and high altitude on the heart and circulation. Am. Heart J. $23: 441$.

Durnin, J. V. G. A., Brockway, J. M. and Whitcher, H. W. 1960. Effects of a short period of training of varying severity on some measurements of physical fitness. J.Appl.Physiol. 15: 161.

Gallagher, J. R. 1944. Static and dynamic physical fitness of adolescents. J.Paed. 20: 81.

Harmenson, L. and Andersen, K. L. 1965. Aerobics and women. J.Appl.Physiol. 20: 432.

Holmegren, A. and Mattsson, K. H. 1954. A new ergometer with constant work load at varying pedalling rate. Scand.J.Clin. Lab. Invest. 6: 14.

Joseph., J. J. 1974. Effects of calisthenics, jogging and swimming on middle aged men. J.Sports Med. \& Phys. Fit. 14: 14. 
Kraus, H. and Prudden, B. 1954. Minimum muscular fitness in school children. Res. Quart. 25: 178.

Le Blance, J. A. 1957. Use of heart rate as an index of work output. J.Appl.Physiol. 10: 275.

Matsui, H., Asmai, T., Iwami, T. and Takeuchi, S. 1964. On the variation of cardiorespiratory function during exercise. ICSS Proc. of International Cong. of Sports Sciences. Ed. by Kitsuo Kato. The Japanese Union of Sports Sciences, Tokyo, 354.

Müller, E. A. 1957. Use of heart rate as an index of work output. J.Appl.Physiol. 10: 275.

Nitu, H., Ito, K., Takagi, K. and Ito, M. 1964. A study on the development of cardiorespiratory function of the oarsmen. ICSS Proc. of the International Cong. of Sports Sciences. Ed. by Kitsuo Kato. The Japanese Union of Sports Sciences, Tokyo, 360.

Schneider, E. C. 1920. A cardiovascular rating as a measure of physical fatigue and efficiency. J.A.M.A. $74: 1507$.

Schneider, E. C. 1931. A study of responses to work on a bicycle ergometer. Am.J.Physiol. 97: 353.

Sharman, I. M., Down, M. G. and Norgan, N. G. 1976. The effects of vitamin-E on physiological function and athletic performance of trained swimmers. J.Sports Med. \& Phys. Fit. 16: 215.

Sjøstrand, T. 1947. Changes in the respiratory organs of workmen at an ore smelting works. Acta Med.Scand. (Suppl.) 196.

Tuttle, W. H. 1950. Effects of physical training on capacity to do work as measured by the bicycle ergometer. J.Appl.Physiol. 2: 393.

Wahlund, H. 1948. Determinations of the physical working capacity. Acta Med.Scand. (Suppl.) 215. 